\title{
The Anthropocene: Are Humans Now Overwhelming the Great Forces of Nature?
}

We explore the development of the Anthropocene, the current epoch in which humans and our societies have become a global geophysical force. The Anthropocene began around 1800 with the onset of industrialization, the central feature of which was the enormous expansion in the use of fossil fuels. We use atmospheric carbon dioxide concentration as a single, simple indicator to track the progression of the Anthropocene. From a preindustrial value of 270-275 ppm, atmospheric carbon dioxide had risen to about $310 \mathrm{ppm}$ by 1950 . Since then the human enterprise has experienced a remarkable explosion, the Great Acceleration, with significant consequences for Earth System functioning. Atmospheric $\mathrm{CO}_{2}$ concentration has risen from 310 to $380 \mathrm{ppm}$ since 1950 , with about half of the total rise since the preindustrial era occurring in just the last 30 years. The Great Acceleration is reaching criticality. Whatever unfolds, the next few decades will surely be a tipping point in the evolution of the Anthropocene.

\section{INTRODUCTION}

Global warming and many other human-driven changes to the environment are raising concerns about the future of Earth's environment and its ability to provide the services required to maintain viable human civilizations. The consequences of this unintended experiment of humankind on its own life support system are hotly debated, but worst-case scenarios paint a gloomy picture for the future of contemporary societies.

Underlying global change (Box 1) are human-driven alterations of $i$ ) the biological fabric of the Earth; ii) the stocks and flows of major elements in the planetary machinery such as nitrogen, carbon, phosphorus, and silicon; and iii) the energy balance at the Earth's surface (2). The term Anthropocene (Box 2) suggests that the Earth has now left its natural geological epoch, the present interglacial state called the Holocene. Human activities have become so pervasive and profound that they rival the great forces of Nature and are pushing the Earth into planetary terra incognita. The Earth is rapidly moving into a less biologically diverse, less forested, much warmer, and probably wetter and stormier state.

The phenomenon of global change represents a profound shift in the relationship between humans and the rest of nature. Interest in this fundamental issue has escalated rapidly in the international research community, leading to innovative new research projects like Integrated History and future of People on Earth (IHOPE) (8). The objective of this paper is to explore one aspect of the IHOPE research agenda-the evolution of humans and our societies from hunter-gatherers to a global geophysical force.

To address this objective, we examine the trajectory of the human enterprise through time, from the arrival of humans on Earth through the present and into the next centuries. Our analysis is based on a few critical questions:

- Is the imprint of human activity on the environment discernible at the global scale? How has this imprint evolved through time?

How does the magnitude and rate of human impact compare with the natural variability of the Earth's environment? Are human effects similar to or greater than the great forces of nature in terms of their influence on Earth System functioning?

What are the socioeconomic, cultural, political, and technological developments that change the relationship between human societies and the rest of nature and lead to accelerating impacts on the Earth System?

\section{Pre-Anthropocene Events}

Before the advent of agriculture about 10000-12000 years ago, humans lived in small groups as hunter-gatherers. In recent centuries, under the influence of noble savage myths, it was often thought that preagricultural humans lived in idyllic harmony with their environment. Recent research has painted a rather different picture, producing evidence of widespread human impact on the environment through predation and the modification of landscapes, often through use of fire (9). However, as the examples below show, the human imprint on environment may have been discernible at local, regional, and even continental scales, but preindustrial humans did not have the technological or organizational capability to match or dominate the great forces of nature.

The mastery of fire by our ancestors provided humankind with a powerful monopolistic tool unavailable to other species, that put us firmly on the long path towards the Anthropocene. Remnants of charcoal from human hearths indicate that the first use of fire by our bipedal ancestors, belonging to the genus Homo erectus, occurred a couple of million years ago. Use of fire followed the earlier development of stone tool and weapon making, another major step in the trajectory of the human enterprise.

Early humans used the considerable power of fire to their advantage (9). Fire kept dangerous animals at a respectful distance, especially during the night, and helped in hunting protein-rich, more easily digestible food. The diet of our ancestors changed from mainly vegetarian to omnivorous, a shift that led to enhanced physical and mental capabilities. Hominid brain size nearly tripled up to an average volume of about $1300 \mathrm{~cm}^{3}$, and gave humans the largest ratio between brain and body size of any species (10). As a consequence, spoken and then, about 10000 years ago, written language could begin to develop, promoting communication and transfer of knowledge within and between generations of humans, efficient accumulation of knowledge, and social learning over many thousands of years in an impressive catalytic process, involving many human brains and their discoveries and innovations. This power is minimal in other species.

Among the earliest impacts of humans on the Earth's biota are the late Pleistocene megafauna extinctions, a wave of extinctions during the last ice age extending from the woolly mammoth in northern Eurasia to giant wombats in Australia (11-13). A similar wave of extinctions was observed later in the Americas. Although there has been vigorous debate about the 


\section{Box 1. \\ Global Change and the Earth System}

The term Earth System refers to the suite of interacting physical, chemical and biological global-scale cycles and energy fluxes that provide the life-support system for life at the surface of the planet (1). This definition of the Earth System goes well beyond the notion that the geophysical processes encompassing the Earth's two great fluids - the ocean and the atmosphere-generate the planetary life-support system on their own. In our definition biological/ecological processes are an integral part of the functioning of the Earth System and not merely the recipient of changes in the coupled ocean-atmosphere part of the system. A second critical feature is that forcings and feedbacks within the Earth System are as important as external drivers of change, such as the flux of energy from the sun. Finally, the Earth System includes humans, our societies, and our activities; thus, humans are not an outside force perturbing an otherwise natural system but rather an integral and interacting part of the Earth System itself.

We use the term global change to mean both the biophysical and the socioeconomic changes that are altering the structure and the functioning of the Earth System. Global change includes alterations in a wide range of global-scale phenomena: land use and land cover, urbanisation, globalisation, coastal ecosystems, atmospheric composition, riverine flow, nitrogen cycle, carbon cycle, physical climate, marine food chains, biological diversity, population, economy, resource use, energy, transport, communication, and so on. Interactions and linkages between the various changes listed above are also part of global change and are just as important as the individual changes themselves. Many components of global change do not occur in linear fashion but rather show strong nonlinearities.

\section{Box 2. The Anthropocene}

Holocene ("Recent Whole") is the name given to the postglacial geological epoch of the past ten to twelve thousand years as agreed upon by the International Geological Congress in Bologna in 1885 (3). During the Holocene, accelerating in the industrial period, humankind's activities became a growing geological and morphological force, as recognised early by a number of scientists. Thus, in 1864, Marsh published a book with the title "Man and Nature," more recently reprinted as "The Earth as Modified by Human Action" (4). Stoppani in 1873 rated human activities as a "new telluric force which in power and universality may be compared to the greater forces of earth" (quoted from Clark [5]). Stoppani already spoke of the anthropozoic era. Humankind has now inhabited or visited all places on Earth; he has even set foot on the moon. The great Russian geologist and biologist Vernadsky (6) in 1926 recognized the increasing power of humankind in the environment with the following excerpt ".... the direction in which the processes of evolution must proceed, namely towards increasing consciousness and thought, and forms having greater and greater influence on their surroundings." $\mathrm{He}$, the French Jesuit priest P. Teilhard de Chardin and E. Le Roy in 1924 coined the term "noösphere," the world of thought, knowledge society, to mark the growing role played by humankind's brainpower and technological talents in shaping its own future and environment. A few years ago the term "Anthropocene" has been introduced by one of the authors (P.J.C.) (7) for the current geological epoch to emphasize the central role of humankind in geology and ecology. The impact of current human activities is projected to last over very long periods. For example, because of past and future anthropogenic emissions of $\mathrm{CO}_{2}$, climate may depart significantly from natural behaviour over the next 50000 years. relative roles of climate variability and human predation in driving these extinctions, there is little doubt that humans played a significant role, given the strong correlation between the extinction events and human migration patterns. A later but even more profound impact of humans on fauna was the domestication of animals, beginning with the dog up to 100000 years ago (14) and continuing into the Holocene with horses, sheep, cattle, goats, and the other familiar farm animals. The concomitant domestication of plants during the early to midHolocene led to agriculture, which initially also developed through the use of fire for forest clearing and, somewhat later, irrigation (15).

According to one hypothesis, early agricultural development, around the mid-Holocene, affected Earth System functioning so fundamentally that it prevented the onset of the next ice age (16). The argument proposes that clearing of forests for agriculture about 8000 years ago and irrigation of rice about 5000 years ago led to increases in atmospheric carbon dioxide $\left(\mathrm{CO}_{2}\right)$ and methane $\left(\mathrm{CH}_{4}\right)$ concentrations, reversing trends of concentration decreases established in the early Holocene. These rates of forest clearing, however, were small compared with the massive amount of land transformation that has taken place in the last 300 years (17). Nevertheless, deforestation and agricultural development in the 8000 to $5000 \mathrm{BP}$ period may have led to small increases in $\mathrm{CO}_{2}$ and $\mathrm{CH}_{4}$ concentrations (maybe about 5-10 parts per million for $\mathrm{CO}_{2}$ ) but increases that were perhaps large enough to stop the onset of glaciation in northeast Canada thousands of years ago. However, recent analyses of solar forcing in the late Quaternary (18) and of natural carbon cycle dynamics $(19,20)$ argue that natural processes can explain the observed pattern of atmospheric $\mathrm{CO}_{2}$ variation through the Holocene. Thus, the hypothesis that the advent of agriculture thousands of years ago changed the course of glacial-interglacial dynamics remains an intriguing but unproven beginning of the Anthropocene.

The first significant use of fossil fuels in human history came in China during the Song Dynasty $(960-1279)(21,22)$. Coal mines in the north, notably Shanxi province, provided abundant coal for use in China's growing iron industry. At its height, in the late 11th century, China's coal production reached levels equal to all of Europe (not including Russia) in 1700. But China suffered many setbacks, such as epidemics and invasions, and the coal industry apparently went into a long decline. Meanwhile in England coal mines provided fuel for home heating, notably in London, from at least the 13th century (23, 24). The first commission charged to investigate the evils of coal smoke began work in 1285 (24). But as a concentrated fuel, coal had its advantages, especially when wood and charcoal grew dear, so by the late 1600 s London depended heavily upon it and burned some 360000 tons annually. The iron forges of Song China and the furnaces of medieval London were regional exceptions, however; most of the world burned wood or charcoal rather than resorting to fuel subsidies from the Carboniferous.

Preindustrial human societies indeed influenced their environment in many ways, from local to continental scales. Most of the changes they wrought were based on knowledge, probably gained from observation and trial-and-error, of natural ecosystem dynamics and its modification to ease the tasks of hunting, gathering, and eventually of farming. Preindustrial societies could and did modify coastal and terrestrial ecosystems but they did not have the numbers, social and economic organisation, or technologies needed to equal or dominate the great forces of Nature in magnitude or rate. Their impacts remained largely local and transitory, well within the bounds of the natural variability of the environment. 


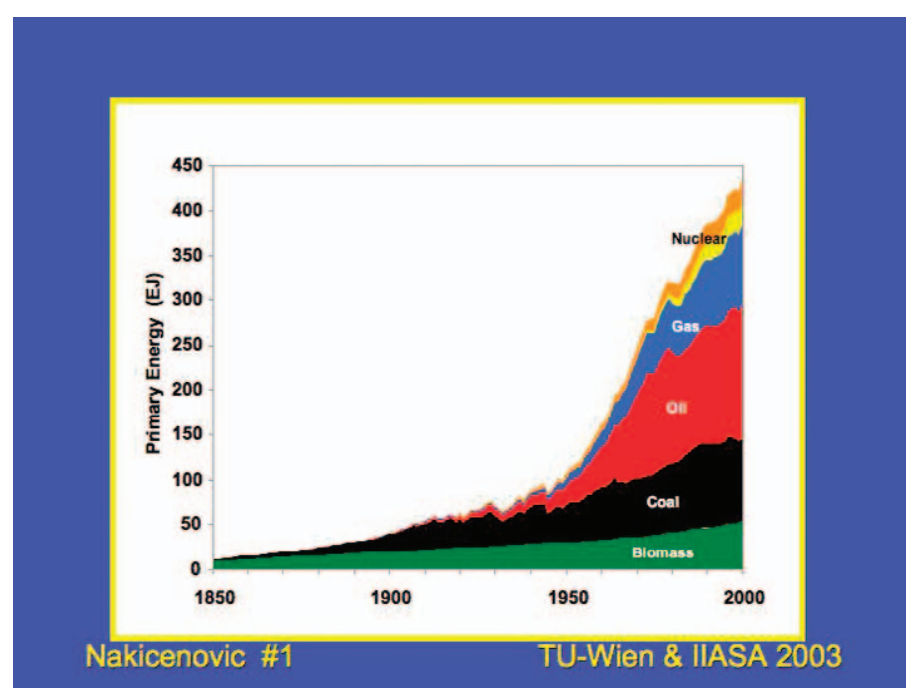

Figure 1. The mix of fuels in energy systems at the global scale from 1850 to 2000 . Note the rapid relative decrease in traditional renewable energy sources and the sharp rise in fossil fuel-based energy systems since the beginning of the Industrial Revolution, and particularly after 1950. By 2000 fossil fuel-based energy systems generated about $80 \%$ of the total energy used to power the global economy.

\section{The Industrial Era (ca. 1800-1945): Stage 1 of the Anthropocene}

One of the three or four most decisive transitions in the history of humankind, potentially of similar importance in the history of the Earth itself, was the onset of industrialization. In the footsteps of the Enlightenment, the transition began in the 1700s in England and the Low Countries for reasons that remain in dispute among historians (25). Some emphasize material factors such as wood shortages and abundant water power and coal in England, while others point to social and political structures that rewarded risk-taking and innovation, matters connected to legal regimes, a nascent banking system, and a market culture. Whatever its origins, the transition took off quickly and by 1850 had transformed England and was beginning to transform much of the rest of the world.

What made industrialization central for the Earth System was the enormous expansion in the use of fossil fuels, first coal and then oil and gas as well. Hitherto humankind had relied on energy captured from ongoing flows in the form of wind, water, plants, and animals, and from the 100- or 200-year stocks held in trees. Fossil fuel use offered access to carbon stored from millions of years of photosynthesis: a massive energy subsidy from the deep past to modern society, upon which a great deal of our modern wealth depends.

Industrial societies as a rule use four or five times as much energy as did agrarian ones, which in turn used three or four times as much as did hunting and gathering societies (26). Without this transition to a high-energy society it is inconceivable that global population could have risen from a billion around 1820 to more than six billion today, or that perhaps one billion of the more fortunate among us could lead lives of comfort unknown to any but kings and courtiers in centuries past.

Prior to the widespread use of fossil fuels, the energy harvest available to humankind was tightly constrained. Water and wind power were available only in favoured locations, and only in societies where the relevant technologies of watermills, sailing ships, and windmills had been developed or imported. Muscular energy derived from animals, and through them from plants, was limited by the area of suitable land for crops and forage, in many places by shortages of water, and everywhere by inescapable biological inefficiencies: plants photosynthesize less than a percent of the solar energy that falls on the Earth, and animals eating those plants retain only a tenth of the chemical energy stored in plants. All this amounted to a bottleneck upon human numbers, the global economy, and the ability of humankind to shape the rest of the biosphere and to influence the functioning of the Earth System.

The invention (some would say refinement) of the steam engine by James Watt in the 1770s and 1780s and the turn to fossil fuels shattered this bottleneck, opening an era of far looser constraints upon energy supply, upon human numbers, and upon the global economy. Between 1800 and 2000 population grew more than six-fold, the global economy about 50 -fold, and energy use about 40-fold (27). It also opened an era of intensified and ever-mounting human influence upon the Earth System.

Fossil fuels and their associated technologies - steam engines, internal combustion engines - made many new activities possible and old ones more efficient. For example, with abundant energy it proved possible to synthesize ammonia from atmospheric nitrogen, in effect to make fertilizer out of air, a process pioneered by the German chemist Fritz Haber early in the 20th century. The Haber-Bosch synthesis, as it would become known (Carl Bosch was an industrialist) revolutionized agriculture and sharply increased crop yields all over the world, which, together with vastly improved medical provisions, made possible the surge in human population growth.

The imprint on the global environment of the industrial era was, in retrospect, clearly evident by the early to mid 20th century (28). Deforestation and conversion to agriculture were extensive in the midlatitudes, particularly in the northern hemisphere. Only about $10 \%$ of the global terrestrial surface had been "domesticated" at the beginning of the industrial era around 1800 , but this figure rose significantly to about $25-30 \%$ by 1950 (17). Human transformation of the hydrological cycle was also evident in the accelerating number of large dams, particularly in Europe and North America (29). The flux of nitrogen compounds through the coastal zone had increased over 10-fold since 1800 (30).

The global-scale transformation of the environment by industrialization was, however, nowhere more evident than in the atmosphere. The concentrations of $\mathrm{CH}_{4}$ and nitrous oxide $\left(\mathrm{N}_{2} \mathrm{O}\right)$ had risen by 1950 to about 1250 and 288 ppbv, respectively, noticeably above their preindustrial values of about 850 and 272 ppbv $(31,32)$. By 1950 the atmospheric $\mathrm{CO}_{2}$ concentration had pushed above 300 ppmv, above its preindustrial value of $270-275 \mathrm{ppmv}$, and was beginning to accelerate sharply (33).

Quantification of the human imprint on the Earth System can be most directly related to the advent and spread of fossil fuel-based energy systems (Fig. 1), the signature of which is the accumulation of $\mathrm{CO}_{2}$ in the atmosphere roughly in proportion to the amount of fossil fuels that have been consumed. We propose that atmospheric $\mathrm{CO}_{2}$ concentration can be used as a single, simple indicator to track the progression of the Anthropocene, to define its stages quantitatively, and to compare the human imprint on the Earth System with natural variability (Table 1).

Around 1850, near the beginning of Anthropocene Stage 1, the atmospheric $\mathrm{CO}_{2}$ concentration was $285 \mathrm{ppm}$, within the range of natural variability for interglacial periods during the late Quaternary period. During the course of Stage 1 from $1800 / 50$ to 1945 , the $\mathrm{CO}_{2}$ concentration rose by about $25 \mathrm{ppm}$, enough to surpass the upper limit of natural variation through the Holocene and thus provide the first indisputable evidence that human activities were affecting the environment at the global scale. We therefore assign the beginning of the 


\begin{tabular}{|c|c|}
\hline Year/Period & $\begin{array}{c}\text { Atmospheric } \mathrm{CO}_{2} \\
\text { concentration }(\mathrm{ppmv})^{1}\end{array}$ \\
\hline \multicolumn{2}{|l|}{$250000-12000$ years $\mathrm{BP}^{2}$ : } \\
\hline Range during interglacial periods: & $262-287$ \\
\hline Minimum during glacial periods: & 182 \\
\hline 12 000-2 000 years BP: & 260-285 \\
\hline \multicolumn{2}{|l|}{ Holocene (current interglacial) } \\
\hline 1000 & 279 \\
\hline 1500 & 282 \\
\hline 1600 & 276 \\
\hline 1700 & 277 \\
\hline 1750 & 277 \\
\hline 1775 & 279 \\
\hline 1800 (Anthropocene Stage I begins) & 283 \\
\hline 1825 & 284 \\
\hline 1850 & 285 \\
\hline 1875 & 289 \\
\hline 1900 & 296 \\
\hline 1925 & 305 \\
\hline 1950 (Anthropocene Stage II begins) & 311 \\
\hline 1975 & 331 \\
\hline 2000 & 369 \\
\hline 2005 & 379 \\
\hline \multicolumn{2}{|c|}{$\begin{array}{l}{ }^{1} \text { The } \mathrm{CO}_{2} \text { concentration data were obtained from: (a) http://cdiac.ornl.gov/trends/trends } \\
\text { htm for the } 250000-12000 \mathrm{BP} \text { period and for the } 1000 \mathrm{AD}-2005 \mathrm{AD} \text { period. More } \\
\text { specifically, data were obtained from ( } 34 ; 250000-12000 \mathrm{BP}),(35 ; 1000-1950 \mathrm{AD}) \text {, and } \\
(42 ; 1975-2000 \mathrm{AD}) \text {. (b) } \mathrm{CO}_{2} \text { concentrations for the } 12000-2000 \mathrm{BP} \text { period (the } \\
\text { Holocene) were obtained from (36). }{ }^{2} \text { The period } 250000-12000 \text { years } \mathrm{PB} \text { encompasses } \\
\text { two interglacial periods prior to the current interglacial (the Holocene) and two glacial } \\
\text { periods. The values listed in the table are the maximum and minimum } \mathrm{CO}_{2} \text { concentrations } \\
\text { recorded during the two interglacial periods and the minimum } \mathrm{CO}_{2} \text { concentration } \\
\text { recorded over the two glacial periods. According to mtDNA evidence, the first appearance } \\
\text { of fully modern humans was approximately } 250000 \text { years BP. }\end{array}$} \\
\hline
\end{tabular}

Anthropocene to coincide with the beginning of the industrial era, in the $1800-1850$ period. This first stage of the Anthropocene ended abruptly around 1945, when the most rapid and pervasive shift in the human-environment relationship began.

\section{The Great Acceleration (1945-ca. 2015): Stage 2 of the Anthropocene}

The human enterprise suddenly accelerated after the end of the Second World War (27) (Fig. 2) Population doubled in just 50 years, to over 6 billion by the end of the 20th century, but the global economy increased by more than 15-fold. Petroleum consumption has grown by a factor of 3.5 since 1960, and the number of motor vehicles increased dramatically from about 40 million at the end of the War to nearly 700 million by 1996 . From 1950 to 2000 the percentage of the world's population living in urban areas grew from 30 to $50 \%$ and continues to grow strongly. The interconnectedness of cultures is increasing rapidly with the explosion in electronic communication, international travel and the globalization of economies.

The pressure on the global environment from this burgeoning human enterprise is intensifying sharply. Over the past 50 years, humans have changed the world's ecosystems more rapidly and extensively than in any other comparable period in human history (37). The Earth is in its sixth great extinction event, with rates of species loss growing rapidly for both terrestrial and marine ecosystems (38). The atmospheric concentrations of several important greenhouse gases have increased substantially, and the Earth is warming rapidly (39). More nitrogen is now converted from the atmosphere into reactive forms by fertilizer production and fossil fuel combustion than by all of the natural processes in terrestrial ecosystems put together (Fig. 3) (40).

The remarkable explosion of the human enterprise from the mid-20th century, and the associated global-scale impacts on
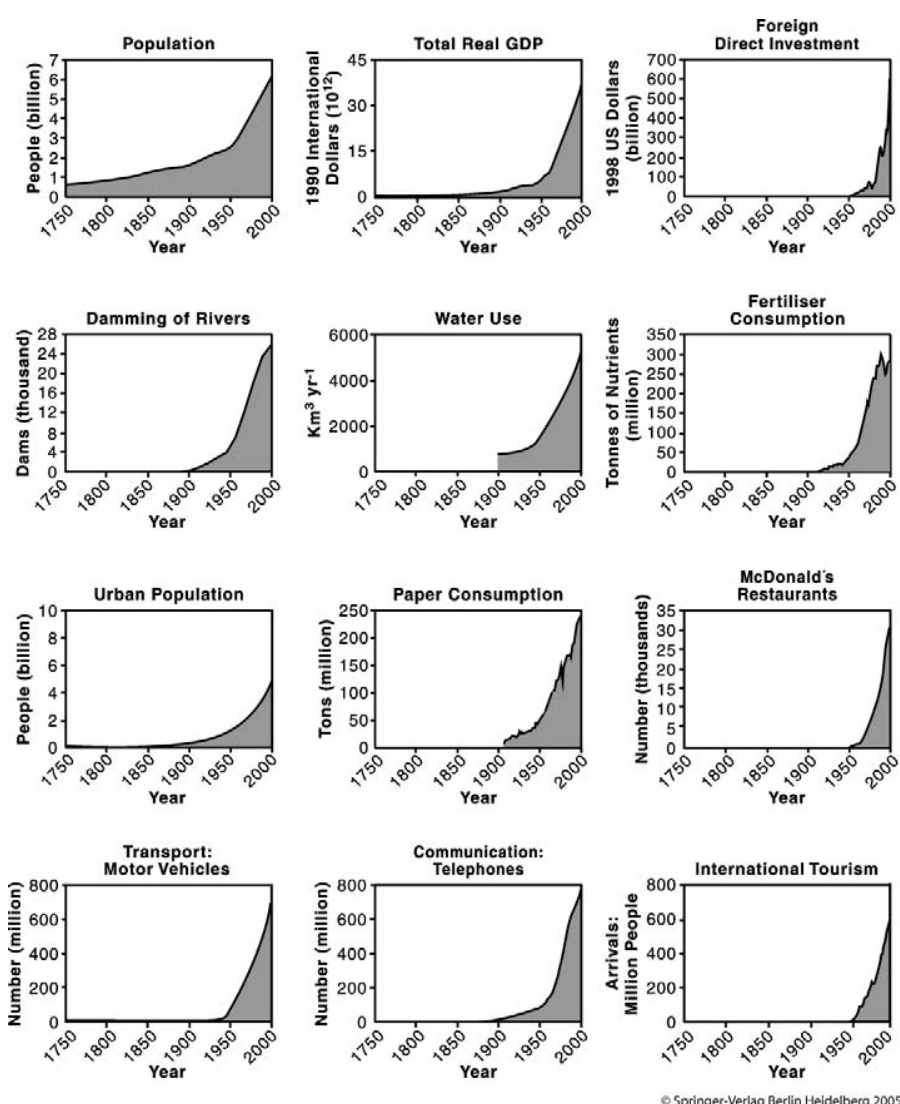

Figure 2. The change in the human enterprise from 1750 to 2000 (28) The Great Acceleration is clearly shown in every component of the human enterprise included in the figure. Either the component was not present before 1950 (e.g., foreign direct investment) or its rate of change increased sharply after 1950 (e.g., population).

many aspects of Earth System functioning, mark the second stage of the Anthropocene-the Great Acceleration (41). In many respects the stage had been set for the Great Acceleration by 1890 or 1910 . Population growth was proceeding faster than at any previous time in human history, as well as economic growth. Industrialization had gathered irresistible momentum, and was spreading quickly in North America, Europe, Russia, and Japan. Automobiles and airplanes had appeared, and soon rapidly transformed mobility. The world economy was growing ever more tightly linked by mounting flows of migration, trade, and capital. The years 1870 to 1914 were, in fact, an age of globalization in the world economy. Mines and plantations in diverse lands such as Australia, South Africa, and Chile were opening or expanding in response to the emergence of growing markets for their products, especially in the cities of the industrialized world.

At the same time, cities burgeoned as public health efforts, such as checking waterborne disease through sanitation measures, for the first time in world history made it feasible for births consistently to outnumber deaths in urban environments. A major transition was underway in which the characteristic habitat of the human species, which for several millennia had been the village, now was becoming the city. (In 1890 perhaps 200 million people lived in cities worldwide, but by 2000 the figure had leapt to three billion, half of the human population). Cities had long been the seats of managerial and technological innovation and engines of economic growth, and in the Great Acceleration played that role with even greater effect.

However, the Great Acceleration truly began only after 1945. In the decades between 1914 and 1945 the Great Acceleration 
Figure 3. Global terrestrial nitrogen budget for (a) 1890 and (b) 1990 in $\mathrm{Tg} \mathrm{N} \mathrm{yr}^{-1}$ (41). The emissions to the NO $y$ box from the coal reflect fossil fuel combustion. Those from the vegetation include agricultural and natural soil emissions and combusion of biofuel, biomass (savanna and forest) and agricultural waste. The $\mathrm{NH}_{\mathrm{x}}$ emissions from the cow and feedlot reflect emissions from animal wastes. The transfers to the fish box represent the lateral flow of dissolved inorganic nitrogen from terrestrial systems to the coastal seas. Note the enormous amount of $\mathrm{N}_{2}$ converted to $\mathrm{NH}_{3}$ in the 1990 panel compared to 1980 . This represents human fixation of nitrogen through the Haber-Bosch process, made possible by the development of fossil-fuel based energy systems.
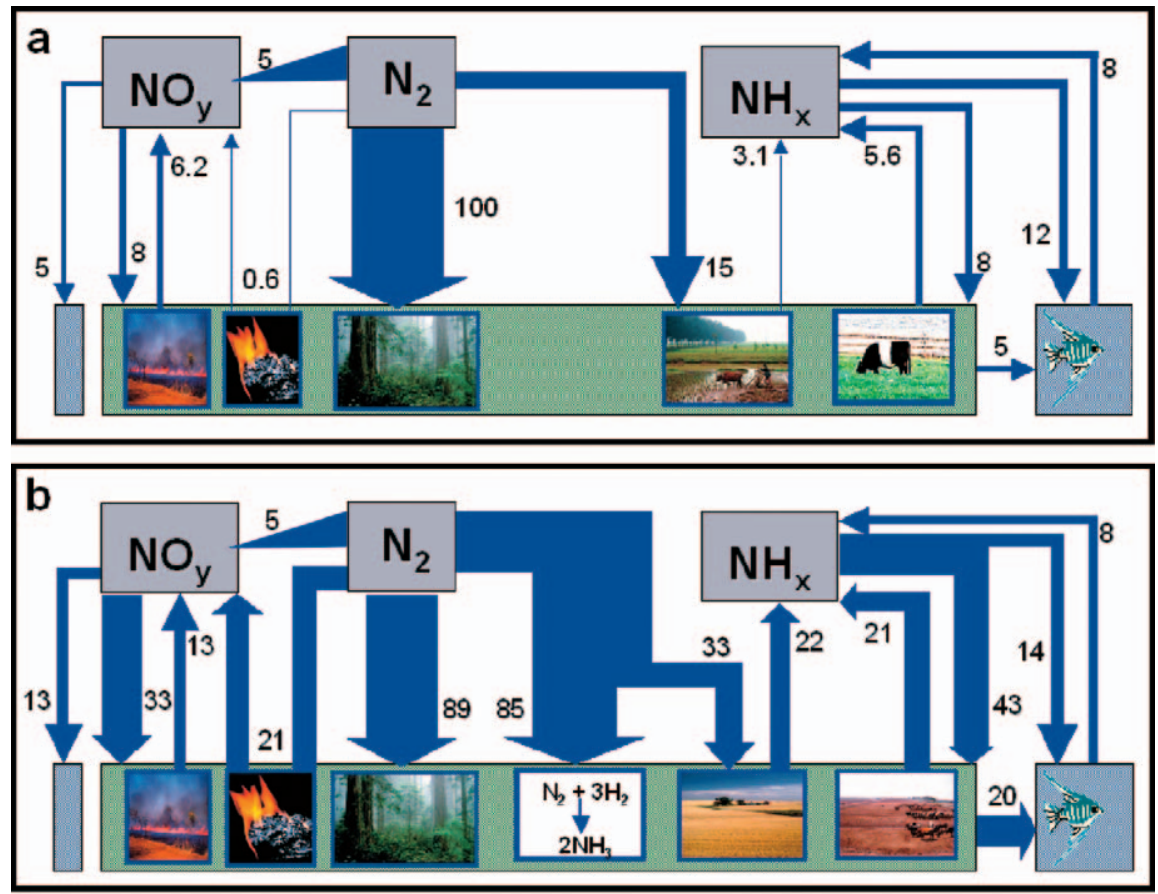

๑) Springer-Verlag Berlin Heidelberg 2005 was stalled by changes in politics and the world economy. Three great wrenching events lay behind this: World War I, the Great Depression, and World War II. Taken together, they slowed population growth, checked - indeed temporarily reversed - the integration and growth of the world economy. They also briefly checked urbanization, as city populations led the way in reducing their birth rates. Some European cities in the 1930s in effect went on reproduction strikes, so that (had they maintained this reluctance) they would have disappeared within decades. Paradoxically, however, these events also helped to initiate the Great Acceleration.

The lessons absorbed about the disasters of world wars and depression inspired a new regime of international institutions after 1945 that helped create conditions for resumed economic growth. The United States in particular championed more open trade and capital flows, reintegrating much of the world economy and helping growth rates reach their highest ever levels in the period from 1950 to 1973 . At the same time, the pace of technological change surged. Out of World War II came a number of new technologies - many of which represented new applications for fossil fuels - and a commitment to subsidized research and development, often in the form of alliances among government, industry, and universities. This proved enormously effective and, in a climate of renewed prosperity, ensured unprecedented funding for science and technology, unprecedented recruitment into these fields, and unprecedented advances as well.

The Great Acceleration took place in an intellectual, cultural, political, and legal context in which the growing impacts upon the Earth System counted for very little in the calculations and decisions made in the world's ministries, boardrooms, laboratories, farmhouses, village huts, and, for that matter, bedrooms. This context was not new, but it too was a necessary condition for the Great Acceleration.

The exponential character of the Great Acceleration is obvious from our quantification of the human imprint on the Earth System, using atmospheric $\mathrm{CO}_{2}$ concentration as the indicator (Table 1). Although by the Second World War the $\mathrm{CO}_{2}$ concentration had clearly risen above the upper limit of the
Holocene, its growth rate hit a take-off point around 1950. Nearly three-quarters of the anthropogenically driven rise in $\mathrm{CO}_{2}$ concentration has occurred since 1950 (from about 310 to $380 \mathrm{ppm})$, and about half of the total rise ( $48 \mathrm{ppm})$ has occurred in just the last 30 years.

\section{Stewards of the Earth System? (ca. 2015-?): Stage 3 of the Anthropocene}

Humankind will remain a major geological force for many millennia, maybe millions of years, to come. To develop a universally accepted strategy to ensure the sustainability of Earth's life support system against human-induced stresses is one of the greatest research and policy challenges ever to confront humanity. Can humanity meet this challenge?

Signs abound to suggest that the intellectual, cultural, political and legal context that permitted the Great Acceleration after 1945 has shifted in ways that could curtail it (41). Not surprisingly, some reflective people noted human impact upon the environment centuries and even millennia ago. However, as a major societal concern it dates from the 1960 s with the rise of modern environmentalism. Observations showed incontrovertibly that the concentration of $\mathrm{CO}_{2}$ in the atmosphere was rising markedly (42). In the 1980s temperature measurements showed global warming was a reality, a fact that encountered political opposition because of its implications, but within 20 years was no longer in serious doubt (39). Scientific observations showing the erosion of the earth's stratospheric ozone layer led to international agreements reducing the production and use of CFCs (chlorofluorocarbons) (43). On numerous ecological issues local, national, and international environmental policies were devised, and the environment routinely became a consideration, although rarely a dominant one, in political and economic calculations.

This process represents the beginning of the third stage of the Anthropocene, in which the recognition that human activities are indeed affecting the structure and functioning of the Earth System as a whole (as opposed to local- and regional-scale environmental issues) is filtering through to decision-making at 
many levels. The growing awareness of human influence on the Earth System has been aided by $i$ ) rapid advances in research and understanding, the most innovative of which is interdisciplinary work on human-environment systems; $i i)$ the enormous power of the internet as a global, self-organizing information system; iii) the spread of more free and open societies, supporting independent media; and $i v$ ) the growth of democratic political systems, narrowing the scope for the exercise of arbitrary state power and strengthening the role of civil society. Humanity is, in one way or another, becoming a self-conscious, active agent in the operation of its own life support system (44).

This process is still in train, and where it may lead remains quite uncertain. However, three broad philosophical approaches can be discerned in the growing debate about dealing with the changing global environment $(28,44)$.

Business-as-usual. In this conceptualisation of the next stage of the Anthropocene, the institutions and economic system that have driven the Great Acceleration continue to dominate human affairs. This approach is based on several assumptions. First, global change will not be severe or rapid enough to cause major disruptions to the global economic system or to other important aspects of societies, such as human health. Second, the existing market-oriented economic system can deal autonomously with any adaptations that are required. This assumption is based on the fact that as societies have become wealthier, they have dealt effectively with some local and regional pollution problems (45). Examples include the clean-up of major European rivers and the amelioration of the acid rain problem in western Europe and eastern North America. Third, resources required to mitigate global change proactively would be better spent on more pressing human needs.

The business-as-usual approach appears, on the surface, to be a safe and conservative way forward. However, it entails considerable risks. As the Earth System changes in response to human activities, it operates at a time scale that is mismatched with human decision-making or with the workings of the economic system. The long-term momentum built into the Earth System means that by the time humans realize that a business-as-usual approach may not work, the world will be committed to further decades or even centuries of environmental change. Collapse of modern, globalized society under uncontrollable environmental change is one possible outcome.

An example of this mis-match in time scales is the stability of the cryosphere, the ice on land and ocean and in the soil. Depending on the scenario and the model, the Intergovernmental Panel on Climate Change (IPCC) (39) projected a global average warming of $1.1-6.4^{\circ} \mathrm{C}$ for $2094-2099$ relative to 1980 1999 , accompanied by a projected sea-level rise of $0.18-0.59 \mathrm{~m}$ (excluding contributions from the dynamics of the large polar ice sheets). However, warming is projected to be more than twice as large as the global average in the polar regions, enhancing ice sheet instability and glacier melting. Recent observations of glacial dynamics suggest a higher degree of instability than estimated by current cryospheric models, which would lead to higher sea level rise through this century than estimated by the IPCC in 2001 (46). It is now conceivable that an irreversible threshold could be crossed in the next several decades, eventually (over centuries or a millennium) leading to the loss of the Greenland ice sheet and consequent sea-level rise of about $5 \mathrm{~m}$.

Mitigation. An alternative pathway into the future is based on the recognition that the threat of further global change is serious enough that it must be dealt with proactively. The mitigation pathway attempts to take the human pressure off of the Earth System by vastly improved technology and management, wise use of Earth's resources, control of human and domestic animal population, and overall careful use and restoration of the natural environment. The ultimate goal is to reduce the human modification of the global environment to avoid dangerous or difficult-to-control levels and rates of change (47), and ultimately to allow the Earth System to function in a pre-Anthropocene way.

Technology must play a strong role in reducing the pressure on the Earth System (48). Over the past several decades rapid advances in transport, energy, agriculture, and other sectors have led to a trend of dematerialization in several advanced economies. The amount and value of economic activity continue to grow but the amount of physical material flowing through the economy does not.

There are further technological opportunities. Worldwide energy use is equivalent to only $0.05 \%$ of the solar radiation reaching the continents. Only $0.4 \%$ of the incoming solar radiation, $1 \mathrm{~W} \mathrm{~m} \mathrm{~m}^{-2}$, is converted to chemical energy by photosynthesis on land. Human appropriation of net primary production is about $10 \%$, including agriculture, fiber, and fisheries (49). In addition to the many opportunities for energy conservation, numerous technologies - from solar thermal and photovoltaic through nuclear fission and fusion to wind power and biofuels from forests and crops - are available now or under development to replace fossil fuels.

Although improved technology is essential for mitigating global change, it may not be enough on its own. Changes in societal values and individual behaviour will likely be necessary (50). Some signs of these changes are now evident, but the Great Acceleration has considerable momentum and appears to be intensifying (51). The critical question is whether the trends of dematerialization and shifting societal values become strong enough to trigger a transition of our globalizing society towards a much more sustainable one.

Geo-engineering options. The severity of global change, particularly changes to the climate system, may force societies to consider more drastic options. For example, the anthropogenic emission of aerosol particles (e.g., smoke, sulphate, dust, etc.) into the atmosphere leads to a net cooling effect because these particles and their influence on cloud properties enhance backscattering of incoming solar radiation. Thus, aerosols act in opposition to the greenhouse effect, masking some of the warming we would otherwise see now (52). Paradoxically, a clean-up of air pollution can thus increase greenhouse warming, perhaps leading to an additional $1{ }^{\circ} \mathrm{C}$ of warming and bringing the Earth closer to "dangerous" levels of climate change. This and other amplifying effects, such as feedbacks from the carbon cycle as the Earth warms (53), could render mitigation efforts largely ineffectual. Just to stabilize the atmospheric concentration of $\mathrm{CO}_{2}$, without taking into account these amplifying effects, requires a reduction in anthropogenic emissions by more than $60 \%$ - a herculean task considering that most people on Earth, in order to increase their standard of living, are in need of much additional energy. One engineering approach to reducing the amount of $\mathrm{CO}_{2}$ in the atmosphere is its sequestration in underground reservoirs (54). This "geosequestration" would not only alleviate the pressures on climate, but would also lessen the expected acidification of the ocean surface waters, which leads to dissolution of calcareous marine organisms (55)

In this situation some argue for geo-engineering solutions, a highly controversial topic. Geo-engineering involves purposeful manipulation by humans of global-scale Earth System processes with the intention of counteracting anthropogenically driven environmental change such as greenhouse warming (56). One proposal is based on the cooling effect of aerosols noted in the previous paragraph (57). The idea is to artificially enhance the Earth's albedo by releasing sunlight-reflective material, such as sulphate particles, in the stratosphere, where they remain for 1-2 

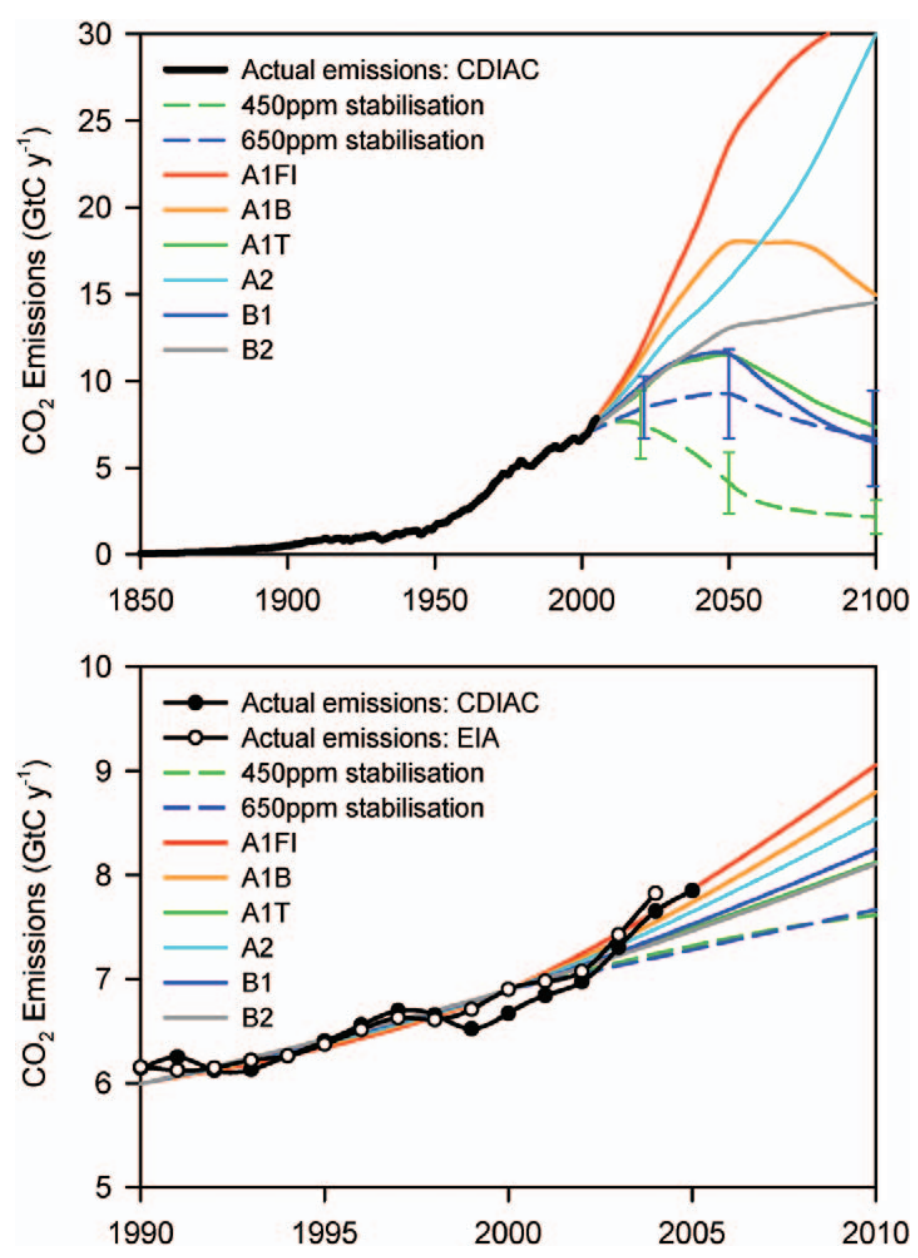

Figure 4. The observed trajectory from 1850 to 2005 of carbon emissions due to fossil fuel combustion (58). Note the acceleration in emissions since 2000. The gap between current emission rates and those required to stabilise atmospheric $\mathrm{CO}_{2}$ concentration at various levels $(450,650$, and $1000 \mathrm{ppm})$ is growing rapidly.

years before settling in the troposphere. The sulphate particles would be produced by the oxidation of $\mathrm{SO}_{2}$, just as happens during volcanic eruptions. In order to compensate for a doubling of $\mathrm{CO}_{2}$, if this were to happen, the input of sulphur would have to be about 1-2 $\mathrm{Tg} \mathrm{S} \mathrm{y}^{-1}$ (compared to an input of about $10 \mathrm{Tg} \mathrm{S}$ by Mount Pinatubo in 1991). The sulphur injections would have to occur for as long as $\mathrm{CO}_{2}$ levels remain high.

Looking more deeply into the evolution of the Anthropocene, future generations of $H$. sapiens will likely do all they can to prevent a new ice-age by adding powerful artificial greenhouse gases to the atmosphere. Similarly, any drop in $\mathrm{CO}_{2}$ levels to low concentrations, causing strong reductions in photosynthesis and agricultural productivity, might be combated by artificial releases of $\mathrm{CO}_{2}$, maybe from earlier $\mathrm{CO}_{2}$ sequestration. And likewise, far into the future, H. sapiens will deflect meteorites and asteroids before they could hit the Earth.

For the present, however, just the suggestion of geoengineering options can raise serious ethical questions and intense debate. In addition to fundamental ethical concerns, a critical issue is the possibility for unintended and unanticipated side effects that could have severe consequences. The cure could be worse than the disease. For the sulphate injection example described above, the residence time of the sulphate particles in the atmosphere is only a few years, so if serious side-effects occurred, the injections could be discontinued and the climate would relax to its former high $\mathrm{CO}_{2}$ state within a decade.
The Great Acceleration is reaching criticality (Fig. 4). Enormous, immediate challenges confront humanity over the next few decades as it attempts to pass through a bottleneck of continued population growth, excessive resource use and environmental deterioration. In most parts of the world the demand for fossil fuels overwhelms the desire to significantly reduce greenhouse gas emissions. About $60 \%$ of ecosystem services are already degraded and will continue to degrade further unless significant societal changes in values and management occur (37). There is also evidence for radically different directions built around innovative, knowledge-based solutions. Whatever unfolds, the next few decades will surely be a tipping point in the evolution of the Anthropocene.

\section{References and Notes}

1. Oldfield, F. and Steffen, W. 2004. The earth system. In: Global Change and the Earth System: A Planet Under Pressure. Steffen, W., Sanderson, A., Tyson, P. Jäger, J., Matson, P., Moore, B. III, Oldfield, F., Richardson, K., et al. (eds). The IGBP Global Change Series, Springer-Verlag, Berlin,Heidelburg, New York, p. 7.

2. Hansen, J., Nazarenko, L., Ruedy, R., Sato, M., Willis, J., Del Genio, A., Koch, D. Lacis, A., et al. 2005. Earth's energy imbalance: comfirmation and implications. Science 308, 1431-1435.

3. Encyclopaedia Britannica. 1976. Micropædia, IX. London.

4. Marsh, G.P. 1965. The Earth as Modified by Human Action. Belknap Press, Harvard Marsh, G.P. 1965. The Earth as Modified
University Press, Cambridge, MA, 504 pp.

University Press, Cambridge, MA, 504 pp.
Clark, W.C. 1986. Chapter 1. In: Sustainable Development of the Biosphere. Clark, W.C. and Munn, R.E. (eds). Cambridge University Press, Cambridge, UK, $491 \mathrm{pp}$.

6. Vernadski, V.I. 1998. The Biosphere (translated and annotated version from the original of 1926). Copernicus, Springer, New York, $192 \mathrm{pp}$.

Crutzen, P. J. 2002. Geology of mankind: the anthropocene. Nature 415, 23.

8. Costanza, R., Graumlich, L. and Steffen, W. (eds). 2006. Integrated History and Future of People on Earth. Dahlem Workshop Report 96, MIT Press, Cambridge, MA, 495 pp. Pyne, S. 1997. World Fire: The Culture of Fire on Earth. University of Washington Press, Seattle, $379 \mathrm{pp}$

10. Tobias, P.V. 1976. The brain in hominid evolution. In: Encyclopaedia Britannica, Macropaedia Volume 8. Encyclopedia Britannica, London, p. 1032.

11. Martin, P.S. and Klein, R.G. 1984. Quaternary Extinctions: A Prehistoric Revolution. Martin, P.S. and Klein, R.G. 1984. Quaternar
University of Arizona Press, Tucson. 892 pp.

12. Alroy, J. 2001. A multispecies overkill simulation of the End-Pleistocene Megafaunal mass extinction. Science 292, 1893-1896.

13. Roberts, R.G., Flannery, T.F., Ayliffe, L.K., Yoshida, H., Olley, J.M., Prideaux, G.J., Laslett, G.M., Baynes, A., et al. 2001. New ages for the last Australian Megafauna: continent-wide extinction about 46,000 years ago. Science 292, 1888-1892.

14. Leach, H.M. 2003. Human domestication reconsidered. Curr. Anthropol. 44, 349-368. 5. Smith, B.D. 1995. The Emergence of Agriculture. Scientific American Library, New York, $231 \mathrm{pp}$.

16. Ruddiman, W.F. 2003. The anthropogenic greenhouse era began thousands of years ago. Climat. Chang. 61, 261-293.

17. Lambin, E.F and Geist, H.J. (eds). 2006 Land-Use and Land-Cover Change: Local Processes and Global Impacts. The IGBP Global Change Series, Springer-Verlag, Berlin, Processes and Global Impacts. The IGBP Global Change Series, Springer-Verlag, Berlin, Heidelberg, New York, 222 pp.

18. EPICA Community Members. 2004. Eight glacial cycles from an Antarctic ice core. Nature 429, 623-628.

19. Broecker, W.C. and Stocker, T.F. 2006. The Holocene $\mathrm{CO}_{2}$ rise: anthropogenic or natural? Eos 87, (3), 27-29.

20. Joos, F., Gerber, S., Prentice, I.C., Otto-Bliesner, B.L. and Valdes, P.J. 2004. Transient simulations of Holocene atmospheric carbon dioxide and terrestrial carbon since the Last Glacial Maximum. Glob.l Biogeochem. Cycles 18, GB2002.

21. Hartwell, R. 1962. A revolution in the iron and coal industries during the Northern Sung. J. Asian Stud. 21, 153-162.

22. Hartwell, R. 1967. A cycle of economic change in Imperial China: coal and iron in northeast China, 750-1350. J. Soc. and Econ. Hist. Orient 10, 102-159.

23. TeBrake, W.H. 1975. Air pollution and fuel crisis in preindustrial London, 1250-1650. Technol. Culture 16, 337-359.

24. Brimblecombe, P. 1987. The Big Smoke: A History of Air Pollution in London since Medieval Times. Methuen, London, $185 \mathrm{pp}$.

25. Mokyr, J. (ed). 1999. The British Industrial Revolution: An Economic Perspective. Westview Press, Boulder, CO, 354 pp.

26. Sieferle, R.-P. 2001. Der Europäische Sonderweg: Ursachen und Factoren. Stuttgart, 53 pp. (In German)

27. McNeill, J.R. 2001. Something New Under the Sun. W.W. Norton, New York, London, $416 \mathrm{pp}$.

28. Steffen, W., Sanderson, A., Tyson, P.D., Jäger, J., Matson, P., Moore, B. III, Oldfield, F., Richardson, K., et al. 2004. Global Change and the Earth System: A Planet Under Pressure. The IGBP Global Change Series, Springer-Verlag, Berlin, Heidelberg, New York, $336 \mathrm{pp}$

29. Vörösmarty, C.J., Sharma, K., Fekete, B., Copeland, A.H., Holden, J., Marble, J. and Lough, J.A. 1997. The storage and aging of continental runoff in large reservoir systems of the world. Ambio 26, 210-219.

30. Mackenzie, F.T., Ver, L.M. and Lerman, A. 2002. Century-scale nitrogen and phosphorus controls of the carbon cycle. Chem. Geol. 190, 13-32.

31. Blunier, T., Chappellaz, J., Schwander, J., Barnola, J.-M., Desperts, T., Stauffer, B. and Raynaud, D. 1993. Atmospheric methane record from a Greenland ice core over the last 1000 years. J. Geophys. Res. 20, 2219-2222.

32. Machida, T., Nakazawa, T., Fujii, Y., Aoki, S. and Watanabe, O. 1995. Increase in the atmospheric nitrous oxide concentration during the last 250 years. Geophys. Res. Lett. 22, 2921-2924.

33. Etheridge, D.M., Steele, L.P., Langenfelds, R.L., Francey, R.J., Barnola, J.-M. and Morgan, V.I. 1996. Natural and anthropogenic changes in atmospheric $\mathrm{CO}_{2}$ over the last 1000 years from air in Antarctic ice and firn. J. Geophys. Res. 101, 4115-4128.

34. Barnola, J.-M., Raynaud, D., Lorius, C. and Barkov, N.I. 2003 Historical $\mathrm{CO}_{2}$ record from the Vostok ice core. In: Trends: A Compendium of Data on Global Change. Carbon Dioxide Information Analysis Cener, Oak Ridge National Laboratory, U.S. DepartDioxide Information Analysis Cenc

35. Etheridge, D.M., Steele, L.P., Langenfelds, R.L., Francey, R.J., Barnola, J.-M. and Morgan, V.I. 1998. Historical $\mathrm{CO}_{2}$ records from the Law Dome DE08, DE08-2, and 
DSS ice cores. In: Trends: A Compendium of Data on Global Change. Carbon Dioxide Information Analysis Center, Oak Ridge National Laboratory, U.S. Department of Energy, Oak Ridge, TN.

36. Indermuhle, A., Stocker, T.F., Fischer, H., Smith, H.J., Joos, F., Wahlen, M., Deck, B. Mastroianni, D., et al. 1999. High-resolution Holocene $\mathrm{CO}_{2}$-record from the Taylor Dame ice core (Antarctica). Nature 398, 121-126.

37. Millennium Ecosystem Assessment. 2005. Ecosystems \& Human Well-bing: Synthesis Island Press, Washington.

38. Pimm, S. L, Russell, G.J. Gittleman, J.L. and Brooks, T. M. 1995. The future of biodiversity, Science 269, 347-350.

39. Intergovernmental Panel on Climate Change (IPCC). 2007. Climate Change 2007: The Intergovernmental Panel on Climate Change (IPCC). 2007. Climate Change 2007: The
Physical Science Basis. Summary for Policymakers. IPCC Secretariat, World Meteorological Organization, Geneva, Switzerland, 18 pp.

40. Galloway, J.N. and Cowling, E.B. 2002. Reactive nitrogen and the world: two hundred years of change. Ambio 31, 64-71.

41. Hibbard, K.A., Crutzen, P.J., Lambin, E.F., Liverman, D., Mantua, N.J., McNeill, J.R Messerli, B. and Steffen, W. 2006. Decadal interactions of humans and the environment In: Integrated History and Future of People on Earth. Costanza, R., Graumlich, L. an Steffen, W. (eds). Dahlem Workshop Report 96. MIT Press, Cambridge, MA, pp 341375 .

42. Keeling, C.D. and Whorf, T.P. 2005. Atmospheric $\mathrm{CO}_{2}$ records from sites in the $\mathrm{SIO}$ air sampling network. In: Trends: A Compendium of Data on Global Change. Carbon Dioxide Information Analysis Center, Oak Ridge National Laboratory, U.S. Department of Energy, Oak Ridge, TN.

43. Crutzen, P. 1995. My life with $\mathrm{O}_{3} \mathrm{NO}_{\mathrm{x}}$ and other $\mathrm{YZO}_{\mathrm{x}}$ s. In: Les Prix Nobel (The Nobel Prizes) 1995. Almqvist \& Wiksell International, Stockholm. pp. 123-157.

44. Schellnhuber, H.-J. 1998. Discourse: Earth System analysis: the scope of the challenge. In: Earth System Analysis. Schellnhuber, H.-J. and Wetzel, V. (eds). Springer-Verlag, Berlin,Heidelberg, New York, pp. 3-195.

45. Lomborg, B. 2001. The Skeptical Environmentalist: Measuring the Real State of the World. Cambridge University Press, Cambridge, UK, $548 \mathrm{pp}$

46. Rahmstorf, S. 2007. A semi-empirical approach to projecting future sea-level rise. Science $315,368-370$

47. Schellnhuber, H.J., Cramer, W., Nakicenovic, N., Wigley, T. and Yohe, G. (eds). 2006 Avoiding Dangerous Climate Change. Cambridge University Press, Cambridge, UK, 406 $\mathrm{pp}$
48. Steffen, W. 2002. Will technology spare the planet? In: Challenges of a Changing Earth Proceedings of the Global Change Open Science Conference. Amsterdam, The Netherlands, 10-13 July 2001. Steffen, W., Jäger, J., Carson, D. and Bradshaw, C. (eds). The IGBP Global Change Series, Springer-Verlag, Berlin, Heidelberg, New York, pp 189 191.

49. Haberl, H. 2006. The energetic metabolism of the European Union and the United States, decadal energy inputs with an emphasis on biomass. J. Ind. Ecol. 10, 151-171.

50. Fischer, J., Manning, A.D., Steffen, W., Rose, D.B., Danielle, K., Felton, A., Garnett, S., Gilna, B., et al. 2007. Mind the sustainability gap. Trends Ecol. Evol. in press.

51. Rahmstorf, S., Cazenave, A., Church, J.A., Hansen, J.E., Keeling, R.F., Parker, D.E., Somerville, R.C.J., et al. 2007. Recent climate observations compared to projections. Science, 316, 709 .

52. Andreae, M.O., Jones, C.D. and Cox, P.M. 2005. Strong present day aerosol cooling implies a hot future. Nature 435, 1187-1190.

53. Friedlingstein, P., Cox, P., Betts, R., Bopp, L., von Bloh, W., Brovkin, V., Doney, V.S Eby, M.I., et al. 2006. Climate-carbon cycle feedback analysis, results from the C ${ }^{4}$ MIP model intercomparison. J. Clim. 19, 3337-3353.

54. Intergovernmental Panel on Climate Change (IPCC). 2005. Carbon Dioxide Capture and Storage. A Special Report of Working Group III. Intergovernmental Panel on Climate Change, Geneva, Switzerland, $430 \mathrm{pp}$

55. The Royal Society. 2005. Ocean Acidification Due to Increasing Atmospheric Carbon Dioxide. Policy document 12/05. The Royal Society, UK, $68 \mathrm{pp}$.

56. Schneider, S.H. 2001. Earth systems engineering and management. Nature 409, 417-421.

57. Crutzen, P. J. 2006. Albedo enhancement by stratospheric sulfur injections: A contribution to resolve a policy dilemma. Clim. Chang. 77, 211-220.

58. Raupach, M.R., Marland, G., Ciais, P., Le Quere, C., Canadell, J.G., Klepper, G. and Field, C.B. 2007. Global and regional drivers of accelerating $\mathrm{CO}_{2}$ emissions. Proc. Nat. Acad. Sci. USA. in press.

59. This paper grew out of discussions at the 96th Dahlem Conference ("Integrated History and future of People on Earth [IHOPE]"), held in Berlin in June 2005. We are grateful to the many colleagues at the Conference who contributed to the stimulating discussions, and to Dr Julia Lupp, the Dahlem Conference organizer, for permission to base this paper on these discussions.

60. First submitted 31 May 2007. Accepted for publication 00 October 2007.
Will Steffen is Director of the Fenner School of Environment and Society at the Australian National University, Canberra. From July 2004 through October 2005, Steffen was Visiting Fellow, Bureau of Rural Sciences, Department of Agriculture, Fisheries and Forestry. From 1998 to mid-2004, he served as Executive Director of the International Geosphere-Biosphere Programme, based in Stockholm, Sweden. His research interests span a broad range within the field of Earth System science, with a special emphasis on terrestrial ecosystem interactions with global change, the global carbon cycle, incorporation of human processes in Earth System modeling and analysis, and sustainability and the Earth System. His address: The Australian National University, Canberra ACT 0200, Australia.

E-mail: will.steffen@anu.edu.au

Paul J. Crutzen is former Director of the Atmospheric Chemistry Division of the Max Planck Institute for Chemistry in Mainz, Germany and is Professor (part-time) at the Scripps Institute of Oceanograpy, University of California, La Jolla, USA. He completed his $\mathrm{PhD}$ and $\mathrm{DSc}$ degrees in meteorology from the University of Stockholm. His research has been mainly concerned with the role of chemistry in climate and biogeochemistry, and in particular the photochemistry of ozone in the stratosphere and troposphere. In 1995 he was awarded the Nobel Prize in Chemistry for his work on the chemical processes leading to the destruction of ozone in the stratosphere. Crutzen's work has also drawn attention to the great importance of the tropics in atmospheric chemistry. In addition, his research has shown the risk of darkness and strong cooling at the earth surface as a consequence of heavy smoke production by extensive fires in a nuclear war ("nuclear winter"). His research over the past 1-2 decades is concerned with the role of clouds in atmospheric chemistry as well as photochemical reactions taking place in marine air. More recently, he has focused on the climatic effects of bio-fuel production, in particular the emissions of $\mathrm{N}_{2} \mathrm{O}$ derived from nitrogen fertilizers. His address: Max Planck Institute for Chemistry, Department of Atmospheric Chemistry, P.O. Box 3060, 55020 Mainz, Germany

E-mail: crutzen@mpch-mainz.mpg.de

John R. McNeill is Professor of History and University Professor at Georgetown University, where until 2006 he held the Cinco Hermanos Chair in International and Environmental Affairs. His research interests lie chiefly in the environmental history of the Mediterranean world, the tropical Atlantic world, and Pacific islands. His most recent books, both global in scope, are Something New Under the Sun: An Environmental History of the Twentieth-century World and The Human Web, co-authored with William $\mathrm{H}$. McNeill. $\mathrm{He}$ is currently finishing a history of yellow fever in the Americas from the 17th to the 20th centuries and beginning a history of fossil fuels. His address: School of Foreign Service, Washington, DC 20057, USA.

E-mail: mcneillj@georgetown.edu 